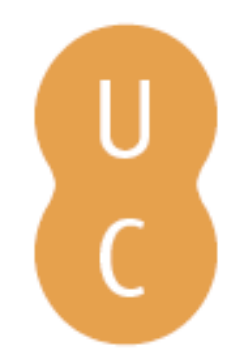

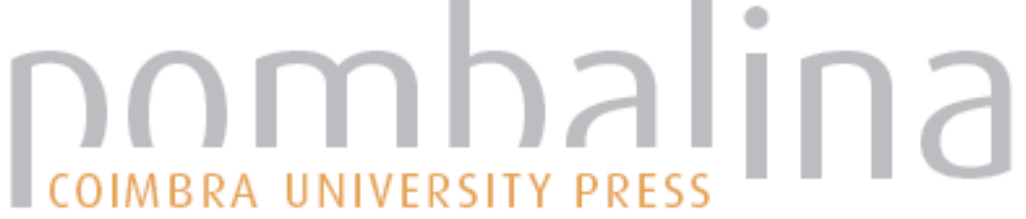

\section{Polycontextural ontology and luhmann's concept of world}

\author{
Autor(es): $\quad$ Pires, Edmundo Balsemão \\ Publicado por: Imprensa da Universidade de Coimbra \\ URL \\ persistente: URI:http://hdl.handle.net/10316.2/31615 \\ DOI: $\quad$ DOI:http://dx.doi.org/10.14195/978-989-26-0205-9_2
}

Accessed : $\quad$ 26-Apr-2023 12:24:20

A navegação consulta e descarregamento dos títulos inseridos nas Bibliotecas Digitais UC Digitalis, UC Pombalina e UC Impactum, pressupõem a aceitação plena e sem reservas dos Termos e Condições de Uso destas Bibliotecas Digitais, disponíveis em https://digitalis.uc.pt/pt-pt/termos.

Conforme exposto nos referidos Termos e Condições de Uso, o descarregamento de títulos de acesso restrito requer uma licença válida de autorização devendo o utilizador aceder ao(s) documento(s) a partir de um endereço de IP da instituição detentora da supramencionada licença.

Ao utilizador é apenas permitido o descarregamento para uso pessoal, pelo que o emprego do(s) título(s) descarregado(s) para outro fim, designadamente comercial, carece de autorização do respetivo autor ou editor da obra.

Na medida em que todas as obras da UC Digitalis se encontram protegidas pelo Código do Direito de Autor e Direitos Conexos e demais legislação aplicável, toda a cópia, parcial ou total, deste documento, nos casos em que é legalmente admitida, deverá conter ou fazer-se acompanhar por este aviso.

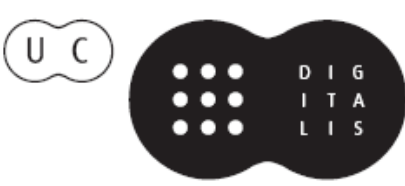


Edmundo Balsemão Pires

Burkhard Nonnenmacher

Stefan Büttner-von Stülpnagel

Editors

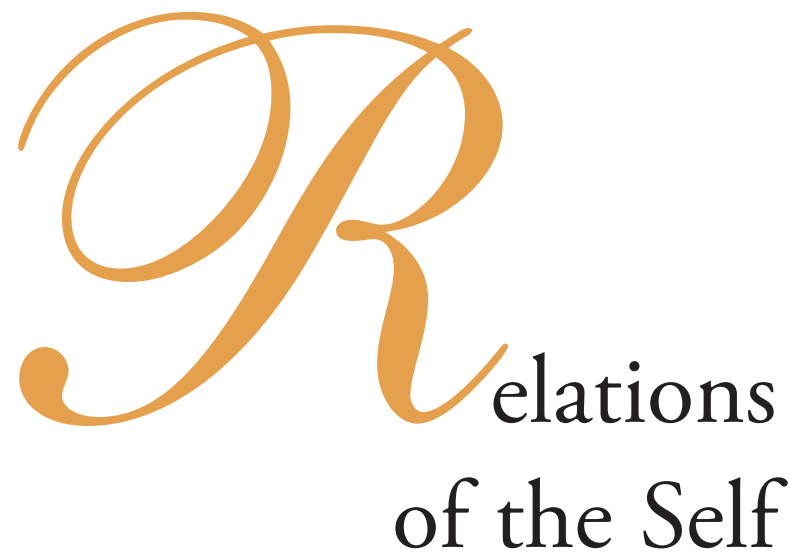




\section{Edmundo Balsemáo Pires \\ Coimbra}

\section{POLYCONTEXTURAL ONTOLOGY AND \\ LUHMANN'S CONCEPT OF WORLD ${ }^{1}$}

\section{Overview}

Günther's work consists chiefly in a plan of a Philosophy of Logic. Rather than being a finished systematic construction of a new logical $n$-valent calculus, its strength lies on the capacity to critically depict the ontological and grammatical foundations of the traditional binary logical mentality. It goes further than propositional Logic. Its object is also different from a conventional propositional calculus.

In the development of his project, Günther connects the need for the examination of the foundations of philosophical Logic with the emergence of research fields and philosophic horizons justifying new tools for the understanding of new difficulties.

I'll summarize some of these new problems in the following:

- the discussion of the topic "order from noise" (cf. Günther's comments on H. von Foerster's vs. Schrödinger's solutions to the problem of the coming out of $\operatorname{life}^{2}$ ) and the formation of systemic boundaries in life morphogenesis;

- the temporal and reflexive horizon of the objects of the Geisteswissenschaften (discussions of the so-called "Positivismusstreit");

- the reflexive object of Cybernetics and the logical problems raised by the new language of machine self-control (see the evolution of the theoretical writings on the foundations of Cybernetics since the $\left.40{ }^{3} s^{3}\right)$;

- a reassessment to the "solutions" for some paradoxes on the foundations of Metamathematics and the problems concerning the relation of Mathematics to Logic (see the

1 The present study is a partial development of the research project on "Individuation of Modern and Contemporary Society" and preserves the essential argument of the initial oral presentation at the International Conference Bezüge des Selbst - Selbstreferentielle Prozesse in Philosophischen Perspektiven, Coimbra, 12-14 March 2009.

${ }^{2}$ G. Günther, “Cybernetic Ontology and Transjunctional Operations” in Idem, Beiträge zur Grundlegung einer operationsfähigen Dialektik, vol. 1., Hamburg, 1976, pp. 274-278.

${ }^{3}$ See C. Pias (Hrsg.), Cybernetics - Kybernetik. The Macy-Conferences 1946-1953. Transactions / Protokolle, 2 Bd., Zürich, Berlin, 2003. 
discussions between intuitionists and formalists since the beginning of the XX century until Gödel's papers ${ }^{4}$ );

- the problem left open by Hegel and the German Classical Philosophy, generally speaking, of the construction of a system of logic adapted to the description of subjectivity, consciousness and reflexion.

Günther's ideas on Philosophy of Logic came from two important books (1933 and 1959): one on Hegel's Logik and a Treatise on a "non-aristotelic "Logic".

From these beginnings resulted a narrative about the actual situation of the logical investigations which tries to depict how binary thinking is anchored on ontological prejudices concerning the form of the articulation of Being and Thought.

The affirmation of the binary oppositions Being /Thought, Being / non-Being, Being / Reflexion is a pre-socratic delineation which the Aristotelic syllogistic formalism consolidates.

According to Günther's narrative even the calculus with functions is aristotelic, because it doesn't defy the well-established consensus of the Metaphysics of Identity and the dualism of its departure point. Thus, in logical matters, what is "aristotelic" is the habit to represent any logical calculus as a set of operations based on binary exclusive combinations reinforced by the "excluded third" principle.

On the other side, excepting other remarkable cases, in the History of Philosophy the socalled "German Idealism" was especially attentive to the limitations of the binary calculus and to the limitations of its identity concept.

From Kant to Hegel one is able to follow essays in order to show why "formal validity" is never an isolated formal validity, but has always ontological underpinnings.

The Hegelian ideas about the conceptual unit of reflexivity, negativity and subjective-objective identity show that the aristotelic legacy represents a calculus with a very limited ontological depth, even if effective and successful.

The XX century separation of the Logistic field from Philosophy leads to a deliberate denial of the Hegelian interrogations but also to the paradoxical result of a general suspicion regarding the possibility and the need of a Philosophy of Logic.

As a consequence, thanks to the unsatisfactory responses to the Hegelian challenges contemporary Philosophy went into directions apparently freed from logical concerns, for instance in the so-called "existentialism", obeying to claims for a thought abstracted from logical constraints or logical rules.

Technical specialized Logistics denying an appropriate Philosophy of Logic and the belief on a thought without logical rules are two faces of the same medal.

In his own description of the nihilistic drive of an hegelianized existentialism, Günther observes (Idee und Grundrib einer nicht-Aristotelischen Logik) that this is an episodic, regional or provincial historical result of European culture and has no "world validity" (Weltgültig).

${ }^{4}$ L. O. Kattsoff, A Philosophy of Mathematics, Ames, Iowa, 1948; J. Largeault (ed.), Intuitionisme et Théorie de la Démonstration, Paris, 1992 ; E. D. Estévez, El Teorema de Gödel, Pamplona, 1975.

${ }^{5}$ G. Günther, Grundzüge einer neuen Theorie des Denkens in Hegels Logik (1933), Hamburg, 1978²; Idem, Idee und Grundriß einer nicht-Aristotelischen Logik (1959), Hamburg, $1991^{3}$. 
The word Welt means two different things in the text: what is worldwide because it is an effect of the dissemination power of the European culture; what is weltgültig allgemein or one could also say worldly-valid as such.

This last aspect means: weltgültig allgemein aber ist nur das, was sich durch den exakten Verstand vermitteln kann (p. 95) ${ }^{6}$. This means that what ensures communication between men can't be inconsistent from a logical point of view. Thus, weltgültig allgemein must be something that obeys to some sort of logical calculus.

But, is it possible to give calculation support for the three main topics of the Hegelian challenge to the traditional System of Logic (mediation, subjective reflexion and reflexion in the other)?

Günther's concept of a Morphogrammatik contains many indications of a calculus that went further than the limited contexture of the binary opposition of Being (object) and Thought (subject). He characterized those aspects of life morphogenesis, I-Thou relations and self-control in machines, in order to make clear the limitations of the classical calculus and the need for new tools.

Along his discussions one finds a systematic use of self-reference, namely when referring the logic-ontological consequences of the admission of a subject-object non-divisible union. However, the pluralism of his methodology led him to the conclusion that the real is structured by infinity of subjective "I-centres" combining I-R-D poles (irreflexive, reflexive and double reflexive) in a variety of combinations. This suggestion represents not only selfreference but a combination of self-reference with a formula for pluralism and contingency.

\section{Arithmetical and logical foundations}

Hegel's ideas on the meaning of the numbers, on Arithmetic and so-called "mathematical method" are noticeable since his earlier writings. They are also important in the Phenomenology of Spirit and later in the Science of Logic.

He conceived the number as a solid, fixed, dead presence. Günther contests this Hegelian depiction as inaccurate with regard to mathematics.

Along his discussion of what a number is in the appendix 2 to Idee und Grundrib..., "Die Metamorphose der Zahl", what the author calls "pythagoric numbers" are easily grouped into two categories: first and second order pythagoric numbers ${ }^{7}$.

The condition of immobility and fixed isolation applies only to first order pythagoric numbers, but not to the second category.

From the Hegelian interpretation of numbers and mathematical reasoning contemporary thinking received the ideas of identity, unity or collections of discrete units of isolated facts. In his writings, Hegel was concerned with the general question of the ontology of numbers and mathematical entities and also with the problem of the possible disagreement between mathematical method and calculation and dialectic.

\footnotetext{
${ }^{6}$ G. Günther, Idee und Grundriß einer nicht-Aristotelischen Logik, Hamburg, 19913, p. 95.

${ }^{7}$ Idem, Idee und Grundriß einer nicht-Aristotelischen Logik, op. cit., pp. 431-479, see especially p. 440.
} 
In the text "Die Metamorphose der Zahl" is shown that pythagoric second order numbers are reflexive units and not discrete, isolated and fixed entities.

How can a number be reflexive?

The author is referring to the possibility expressed by so-called self-referential Richard's numbers.

We know that Gödel used some recursive characteristics of Richard's numbers in his famous account of the relation of mathematics to metamathematics.

Second order pythagoric numbers or Richard's numbers have two main general features: an ordinal relation to cardinal numeric expressions; the ability to quote a position in a numeric series from another position in another isomorphic series.

Second order pythagoric numbers operate as labels for instance in such ex-pressions: the dyad, the triad, etc. Here, we have a quotation or a number whose content is another number. "A diad" refers to a group of two members, and as a label it designates itself as a certain unit, a unit made of two members. With this very generic clarification we understand now why Pythagoric second order numbers are reflexive numbers ${ }^{8}$.

According to the "appendix 2" we have to scrutinize this capacity of recursion, or selfquotation, of the numeric series. If we envisage this arithmetic characteristic we see that numeric self-reflexion occurs only if we add a unit to a dyad $(2+1)$ making the number 3 or 3 units.

Hegel's conception on the fixed character of the numeric series starts from the conviction that the unity, (the one), is the number that repeats itself incessantly along the progression of natural numbers $(\mathrm{N})$.

But it is possible to show that the Hegelian notion of Vermittlung is a reflexive feature also present in second order pythagoric numbers and in the general capacity of numeric iteration.

As a Vermittlungsnummer is number 3 only $2+1$ or has it the additional meaning of the beginning of the pythagoric numbers of the second order?

Hegel identified some characteristics of the number 3 with the logical and ontological value of mediation and reflexion.

Can we understand the arithmetic recursion as a special case of reflexion and mediation?

The concept of something real wouldn't be complete without a third term between or beyond the immediate subject - object relation, because the very concept of reality entails the conception of something independent of the subjective, immediate, non recursive, reflexion.

Günter's originality consists in the essay to understand the sequence of the three first numbers from a logical-arithmetic perspective, but entailing recursion, reflexion and mediation.

Let me summarize his essay.

i) Initially, the 3 as $2+1$ expresses the fact that there is no exclusive negation between 1 and 2 , but a generative passing through.

ii) Now, if we take 1 and 2 as equivalents to the logical values of 01 , or false and true, it is easy to see how the new number resulting from the sum $2+1$ is not reducible to the same 01 values or true and false.

\footnotetext{
${ }^{8}$ Idem, Ibid., p. 441 and p. 444.
} 
iii) Additionally, if with 3 we understand that the immediate negation of 1 and 2 is not an exclusive, fixed, negation, this entails that what the immediate negation is only appears from the positive position of 3 and not otherwise.

If we identify 1 and 2 with the cognitive functions of object and subject we shall conclude that 3 represents simultaneously a new form and also a repetition of the unity 1 .

From these consequences it is possible to conclude: Das Wirkliche ist nicht auf eine Dyadik reduzierbar?.

Consequently, he continues, the bivalent logic mobilized a system with a rigorous isomorphism between both values, with no exteriority or reflexive distance: Das Sein saugt alles auf ${ }^{0}$.

However, the concept of reality (1) doesn't mean the simple appearance of something that stays there for an isolated subject-observer (2), but entails reflexive repetition (3): (...) Als das Einmal-Erschaffene hat es eine subjective, eine objective und eine wiederholende Seite ${ }^{11}$.

Only in the position 3 it is possible to secure the two values of the bivalent logic, which means that as a system of logic an absolute bivalent frame is imperfect and incomplete.

But, what is the logical and ontological correlate of the 3 ?

From the point of view of the arithmetic use of natural numbers this question is pure "non-sense", but it is not so if we take the number 3 as a result of the two first natural numbers and, additionally, if we give to the series a logical value. Indeed, the bivalent frame of the conventional logic is also a calculus based on the belief on the capacity of the dyad to perform the majority of calculus related to formal thinking.

The identity of a system that refers to itself can't be established with the help of a twovalued logical system with two values referring to independent, non-recursive, hetero-referent entities. Only a three-valued system can do the basic task concerning the establishment of the identity of a bivalent system.

\section{From the meaning of arithmetic recursion to an Ontology of Reflexion}

I'll begin to notice that Günther's use of the concept of value doesn't have the restricted meaning of logical "value".

In the classical tradition the third represented two things: the excluded and the negation.

Is there a relation between these two meanings?

There is yet another important possibility if we remember that the third also means the reflexion or subjectivity.

The possibility of the representation of the subject by the third value also entails the need for a logical place denoting the negation of the subject or the negation of the immediate reflexion. This reflexion of a second order demands a fourth logical value, that is clear when

\footnotetext{
${ }^{9}$ Idem, Ibid.,p. 441.

${ }^{10}$ Idem, Ibid.,p. 464.

${ }^{11}$ Idem, Ibid.,p. 441.
} 
we realize that a third-value system can't describe the complete structure of the inner link between negation, mediation and reflexion.

This internal connection will deserve special attention. From the point of view of the bivalent frame four (4) simply appears as negation of three (3).

But, in his texts, Günther distinguished between total negation and incomplete negation.

Total negation means here a reflexion on the value of negation itself which is only available on the ground of a fourth-valued logical frame $(3+1)$.

Thus, the three-valued logic is only a first step in the way to a more complete logical conception of negation, mediation and reflexion.

The third in the three-valued logic is equivalent to what is called rejection value. What represents this rejection value?

He represents the negation of the completeness and self-sufficiency of the dyad.

The introduction of the third only reveals the need for a richer image of reflexion, but can't describe the fact of the plurality of reflexion centres ("I-centres").

In the domain of philosophical doctrines the distinction between value 3 and value 4 is illustrated in the difference between Hegel and his conception of the self-movement of the reflexion of the Absolute and Plato with his dialogic exposition of Science which requires always a plurality of reflexive approaches to the real.

From the comparison between Aristotelic-Hegelian and Platonic heritages Günther concludes that the concept of the reflexion of a universe entails the concept of the possible plurality of reflexion centres and these are expressed by a fourth-valued logical system. The $3+1$ indicates that an extra value (+) 1 is needed in order to reveal other reflexion centres.

With his proposal of a fourth-valued logical system the author projected the conciliation between the ontological perspectives whose reference is an objective world and the polymorphic reflexion that justifies the idea of a distribution of "I-centres" with no hierarchical subordinations but organized within a heterarchic structure.

The text "Cybernetic Ontology and Transjunctional Operations" results from a combination of these two orientations.

From this perspective it is possible to achieve a well-informed critique of Hegel. Within Günher's own programme this one will start from the critique of an exhaustive identity between Being and Thought ${ }^{12}$.

It is possible to condense in a group of few questions the claims of this research programme.

1. We know that the predominant system of logic is "aristotelic" and bivalent. This system entails a Logic of Being and not the Logic of the multiplicity of Reflexion centres. Its starting point is the polarity between the objective being and a unique centre of subjective reflexion. This model is not tailored for the understanding of modern Cybernetics or life morphogenesis.

${ }^{12}$ The alternative Being and Thought, Object and Subject, is also the polarisation required for the identity scheme of the ancient Metaphysics and for the Hegelian absolute identity. Even if this is a non-intended result of Hegel's nonbinary thinking one shall avoid the appeal of an exhaustive identity. Günther prefers to say that being and thought are only partially "identical”. See Idem, Ibid., p. 91; Idem, „Der Tod des Idealismus und die letzte Mythologie“ (unpublished manuscript in possession of Staatsbibliothek Preußischer Kulturbesitz, available at www.vordenker.de). 
2. A decisive investigation consists in the development of logical tools adapted for the calculation of at least three logical values in accordance with the need for an extended Logic of Reflexion.

3. The internal relation of the values in the non-aristotelic logic is different from the relation of the values in the traditional logic. The problem consists now in the construction of an adequate, operational, frame for calculations with reflexive values, such as simple reflexion and double reflexion, and values resulting from mediations. I'll emphasize this aspect: the new system of logic can't be reduced to a conceptual theory and calculation of the nonreflexive, objectivised being.

An "operative definition of subject" is thus needed for the new programme of a Logical discipline valid for Cybernetics, but also for a general conception about the meaning of the difference between physical systems, biological systems (and social systems).

\section{Plurality of real-reflexive structures}

In the text "Die klassische Metaphysisk und das Problem der Kybernetik"13 Günther developed his version of the classical concept of analogy trying to enlarge its meaning to include the problem of the consciousness of machines.

The starting point of the analogy is the hypothesizing that Human consciousness is to a certain extent analogous to God's knowledge: both participate in negativity and in negative relations to what is not conscious or "material bodies".

The coverage area of the analogy goes from God's consciousness to its negative polarity, the material inanimate thing, passing through the Human consciousness, animals (and animal souls) and machines endowed with "self-awareness". Along this complex analogy area the meaning of consciousness is not always the same and, as we said before, what we call Human consciousness is in the middle between God's archetype self-awareness and, on the other side, animal souls and self-aware machines.

A particular theoretical problem concerns the status of this machine "self-awareness".

Are we dealing here with an analogous of human consciousness?

And if negation is at the core of consciousness what is the relation between negation and the self-awareness in machines?

The complete domain of analogical relations supposes the idea of self-awareness which is a notion common to some "negative" machines, animals, humans and God.

The comparison supposes that in the case of machines we face not only material things subjected to physical causality, but we deal also with meaning connections, or so called sinnvolle Bedeutungsmotive.

The accuracy of the analogy scheme raises the need for a reappraisal of the ancient opposition between material things and soul (Dinge und Seele). If we acknowledge reactions to meaning in artefacts this may mean that we are dealing with analogous forms of consciousness, so called self-awareness and a degree of reflexion and negativity.

${ }^{13}$ Idem, "Die klassische Metaphysisk und das Problem der Kybernetik" in Idem, Das Bewusstsein der Maschine. Eine Metaphysisk der Kybernetik, Baden-Baden, 1963, pp. 19-46. 
The traditional categories used for the recognition of material things were the categories of external identity hypothesized by an independent observer, measurable extension or infinity, the negative notions of absence of consciousness, subordination to general causal laws and absence of free will.

Günther summarizes all these categories in the classical logical identity concept.

Consciousness or analogue forms of consciousness don't possess bare identity, but "reflexive identity". A-temporal, non-fragmented identity, is a characteristic of things but not of consciousness. This one, says the philosopher in the second part of Das Bewubtsein der Maschinen, ist nie völlig identisch mit sich selbst ${ }^{14}$. On the contrary, he continues, the objectivity of material things entails logische Irreflexivität ${ }^{15}$.

Consciousness is essentially re-turning upon oneself and, consequently, there is no consciousness without self-division.

Self-division means: a repetition of an initial distinction that submits itself to replication or recursion.

In the recursive iteration is generated a difference that refers to itself. Thus, consciousness can refer to itself using the form of the thing-object and the form of consciousness-act. This also means that in the making of objectivity one has to deal with reflexive structures and forms born from self-division.

Additionally, I would like to stress that self-division and recursion from division is an essential trait of the individuation processes, generally speaking.

Briefly, reflexive individuality means a contingent unit recursively referring to itself across a plurality of self-differentiations.

We have to solve the problem of the inclusion of other forms of self-awareness, reflexion and reflexive self-division and recursion in an adequate logical system which can't be limited to two values.

Starting from the initial duality of subject and object, Günther shows how the subjective pole can't be without reflexion upon itself, self-division and recursion of self-division. $\mathrm{He}$ refers this last mode of reflexion as double reflexion ${ }^{16}$.

However, if we are attentive to his suggestion we see that he is referring a model of the individuation of the cognizing subject. Subject and consciousness are unsatisfactory labels to the denotation of this dynamics of self-division and recursion in the cognitive process that occurs always in located and contingent processes.

Classic Logic revealed marked indifference towards the importance of double reflexion, because its frame implied always the disjunctive alternative between subjectivity and objectivity, mind and matter, thought and being. For the acknowledgement of double reflexion one needs at least three logical-ontological positions ${ }^{17}$.

${ }^{14}$ Idem, "Mechanismus, Bewußtsein und nicht-Aristotelische Logik" in Idem, Das Bewusstsein der Maschine. Eine Metaphysisk der Kybernetik, op. cit., p. 50.

${ }^{15}$ Idem, Ibid., p. 53.

${ }^{16}$ Idem, Ibid., p. 53.

${ }^{17}$ Here one finds the justification for what the philosopher called trinitarische Metaphysik which he states in the following: an Stelle einer klassischen Identitätsmetaphysik erhalten wir jetzt den Grundriß einer trinitarischen 
I - "Irreflexivität"

R - Reflexion

D- Double Reflexion ${ }^{18}$

The problem now could be the drawing of conditions for the projection of the triadic structure of double reflexion in a bivalent frame.

Such projection is a reduction and reduction means the move from relations between three terms to relations grounded on pairs of terms. In many texts Günther examined this question.

The reduction of three or more terms to pairs saves only a part of the meaning of the double reflexion, because according to traditional Logic between $\mathrm{R}$ and I one can only establish a negative relation characterized by the rule of double exclusion and third excluded: $\mathrm{R}$ is not what $\mathrm{I}$ is and $\mathrm{I}$ is not what $\mathrm{R}$ is and there are not other alternatives.

If we add $\mathrm{D}$ to this initial duality we must combine $\mathrm{D}$ with $\mathrm{I}$ and $\mathrm{D}$ with $\mathrm{R}$, etc., always by pairs. Taking the example of conjunction and disjunction in the "truth tables" Günther shows that the combination between pairs requires the generation of three different tables for I-R-D relations.

Additionally, there is the problem of the availability of the Hegelian distinction between immediate relations and mediation through operations.

This last distinction creates a rule for the combination of the terms. For instance, I and $\mathrm{D}$ can't be conceived as immediate values, because their relation supposes the mediating role of R. But, bivalent traditional logic has no means to describe such thing as the self-mediation of thought.

The concept of the Thou has some properties that detach its content from the content of the concept of subject (or the I) as well from the content of the concept of an external, material thing, the so-called object. The Thou is neither object nor subject. Additionally, continuing our description of its properties, we discover that the Thou also means in a positive form this neither / nor. Indeed, the Thou means another subjective autonomy regarding the objective world of things.

According to an historical and conceptual description the I-Thou relation is situated at the intersection point of a relation of analogy and the notion of reciprocity between "relata".

The relation of analogy was also essential in the traditional description of the movement from God towards the creation and especially towards the human intelligence of God's creation. However, the meaning of the intersubjective analogy is distinct from "analogia entis" and a complete identification of both is not adequate.

The "analogia entis" tradition is markedly based on the vertical relation God-creation even if one conceives God internally as a Trinitarian dialogue.

But the relation God-creation and the theological and metaphysical discourse on the creation of the world can't be the prototype of the relation between different human subjects $^{19}$. Günther didn't develop special analysis concerning the phenomenological (husserlian)

\footnotetext{
$\overline{M e t a p h y s i k, ~ d a ~ d i e ~ I n-a ̈ q u i v a l e n z ~ v o n ~ D e n k e n ~ u n d ~ S e i n ~ d a r a u f ~ h i n d e u t e t, ~ d a \beta ~ d i e ~ W e l t ~ n i c h t ~ e i n e, ~ s o n d e r n ~ d r e i ~}$ metaphysischen Wurzeln hat. (Idem, Idee und Grundriß einer nicht-Aristotelischen Logik, op. cit., p. 91).

${ }^{18}$ Idem, Ibid., pp. 52-53.

${ }^{19}$ Idem, Ibid., pp. 58-59.
} 
use of the concept of analogy (along the fifth Cartesian Meditation). But we can imagine the objections. Indeed, Husserl, in his phenomenological theory of constitution, starting from the ego as the primordial source of constitution of the world and of alien life blocks the possibility of a description grounded on an original multiplicity of reflexion centres and on an equal originality of the I and the Thou. Alternative possibilities as Sartre's and Scheler's are also insufficient.

The Thou is a third, apart from the I and the Object, and free from both. But this recognition entails an additional thesis regarding the concept of the reflexion. Reflexion doesn't occur analogically through the I but instead supposes a real duality of I and Thou.

This last idea implies contingency and, consequently, the discovery of ways to make sense of individuated subjective-real forms.

Reflexion demands real difference and not an expanded subjective identity from an originator transcendental I. The distinction between the I and the Thou polarizes the structure of reflexion and also the reference to reality. Quoting Schelling, but also showing the limitations of the philosopher's starting point, Günther wrote: Welt, Ich und Du sind die drei Momente, aus denen sich ... der Prototyp aller Existenz zusammensetzt ${ }^{20}$.

If we start from the reference to the multiplicity of reflexive centres of reality we should also state the principle of the non-reducible plurality of such reflexive centres. This requires a logical structure with three values and not a binary combination of only two values, if logic and logical values are really adequate expressions of the structure of reflexion. Thus, as we saw before, the double reference to the subject demands, at least, a three-valued logic. This threevalued logic will demand a three-valued logical calculus and for the closure of a three-valued logical-ontological space we will need an additional value, the $4^{21}$.

And, also, it demands the recognition of the non-reducibility of the individual ground of subjectivity and consciousness that among other consequences implies the clear separation of persons and the numeric distinction of me and you. In my view, Günther didn't insist on this point, sufficiently.

According to his schemes in "Mechanismus, Bewußtsein und nicht-Aristotelische Logik" the so-called "analogy domain" is enlarged to include the "animal realm", generally speaking. Such enlargement introduces more complexity in the starting point. But, if we recognize the importance of a place to animals in the complete "analogy domain", thus generating a tetradic analogical structure, we may (and shall) go further and recognize also a place for robots and what we call today "artificial intelligence" which expresses a "consciousness-like" behaviour or what one may call "self-awareness in machine behaviour" 22 .

\footnotetext{
${ }^{20}$ Idem, Idee und Grundriß einer nicht-Aristotelischen Logik, op. cit., p. 83. Günther continues his explanation of the need for the three-valued calculus commenting aspects of Schelling's late Philosophy, namely the distinction between two sorts of negativity: the infinite negation of the intransitive possibility and the transitive possibility (Idem, Ibid., p. 84). From his commentary he comes to two conclusions: 1. "Sein und Denken sind nur partiell identisch"; 2. „Das Objekt hat eine, das Subjekt hat zwei metaphysiche Wurzeln“ (Idem, Ibid., p. 85). According to his thesis the two theorems here explained are incompatible with the traditional logical binary concept of reflexion, which entails a complete identity (or unsolved binary opposition) between Being and Thought.

${ }^{21}$ Idem, "Die Metamorphose der Zahl” in Idem, Ibid., p. 457.

${ }^{22}$ Idem, "Mechanismus, Bewußtsein und nicht-Aristotelische Logik" in Idem, Das Bewusstsein der Maschine. Eine Metaphysisk der Kybernetik, op. cit., p. 59-60. See also Idem, "Seele und Machine" in Beiträge zur Grundlegung einer operationsfähigen Dialektik, vol. 1., op. cit., pp. 75-90.
} 
According to this pluralistic theory of the Real the acknowledgment of a real plurality of reflexive centres implies a critical appreciation of the traditional refusal of Time in Logic.

There is an obvious correspondence between a timeless Logic and the current understanding of four logical rules: the absolute validity of the principle of the excluded third; the opposition between designative and non-designative; the conversion of the designative / non-designative distinction on the assertion / negation polarity; the duality between conjunction and disjunction.

Individuated reflexivity and time are two decisive focuses for a critical reassessment to the logical tradition but also stimulus for a positive Philosophy of Logic.

Günther returns to the Aristotelic Peri Hermeneias, IX, to find an instructive and symptomatic "logical use" of time regarding the "contingent futures".

I will not scrutinize either the variety of aspects of the long reception of the aristotelic theory of modalities or the contemporary modal theories.

Thus, summarizing dramatically: 1 . if we agree that the concept of time applies to events not yet produced, we don't have conditions to unequivocally apply them the concept of truth, as if we knew what they are; 2 . consequently $(i)$, we have reasons to deny unrestricted formulations of the principle of the excluded third but we don't have good reasons to absolutely cancel its validity; 3 . consequently (ii), we need to envisage the problem of the logical meaning of time without eradicate time itself but ascertain to time an autonomous position.

Günther paid attention to this task (ii) and tried to symbolize what could be a new logical position for time he called the kenogramme ${ }^{23}$. Kenogrammatic structures are representations of positions that oscillate from pleroma, or plenitude, to emptiness, or kenoma. They are more or less complex generative sequences of forms.

The introduction of the variable time in the logical space means a deep change in the Being - Thought relation, because the primary value brought by time is the contingency of the designative and non-designative poles of the relation.

What moved on to the centre is the binary occupation / non-occupation of valuepositions intended for the indication of forms generation.

The recent investigation of the connections between kenogrammatic structures, contextures and time is due to R. Kaehr ${ }^{24}$ and an application of kenogrammatic logic to presemiotic and semiotic forms, also based on M. Bense's semiotic proposals, is available in the writings of A. Toth ${ }^{25}$.

\section{Contextures and the meaning of the excluded third}

By different occasions Günther reminds us the very disputable character of the principle of tertium non datur in Metamathematics. In the logical field we may conclude that in a

\footnotetext{
${ }^{23}$ See G. Günther and H. von Foerster, "The Logical Structure of Evolution and Emanation" first published in Ann. N. Y. Acad. Sci.138 (1967), pp. 874-891, also available at www.vordenker.de.

${ }^{24}$ R. Kaehr, "KOMPASS. Expositionen und Programmatische Hinweise zur weiteren Lektüre der Schriften Gotthard Günthers" in Ernst Kotzmann (Hg.), Gotthard Günther - Technik, Logik, Technologie, München / Wien, 1994, pp. 81-125.

25 See, among other writings, A. Toth, „Kenogrammatic, Präsemiotik und Semiotik“ available at http://www.mathematicalsemiotics.com/articles.html
} 
three-valued calculus the rejection of the conversion of double negation in affirmation entails the rejection of tertium non datur and also the limitation of the principle of noncontradiction. Thus, it is the whole traditional system of logic that is under revision, because such system is grounded on the binary opposition between subject and object, thought and being.

Russell's discussion of the self-referential arguments was strictly related to the meaning of the excluded third in Logic and Mathematics. According to him, this principle was expressed on an unequivocal self-referential form, because it is impossible to distinguish its content from the application to itself. This entails a paradoxical sentence.

Concerning the principle of the excluded middle R. B. Ramsey, in his study on "Mathematical Logic" (1926), also noted the difficulty in giving a proof of this logical principle $^{26}$, commenting and correcting Brouwer demonstration of its falsehood. He sustained that Brouwer was excessively radical in his rejection of the tertium non datur and the consequence was the impossibility of the justification of the "ordinary mathematics".

The author explained also how by $\mathrm{H}$. Weyl this problem had an application in the field of the explanation of integers or real numbers. "A real number is given by a sequence of integers, for instance as an infinite decimal, this sequence we can conceive as generated either by a law or by a successive acts of choice" 27 .

His depiction of Hilbert's opposite formalist system justifies the understanding of mathematics as "manipulation of meaningless symbols according to fixed rules" 28 . According to Hilbert, Mathematics is an axiomatic building, which begins from a set of primitive statements associated with rules of deduction to derive other statements. The analogy between mathematics and games is direct. Metamathematics is another level of mathematic reasoning which demands the capacity to analyse when such and such formulas were derived according to proper rules of derivation. The most important theorem of metamathematics states that it is impossible to derive from the axioms statements that contradict such axioms. Thus, Hilbert puts the tertium non datur as a primary rule of metamathematics.

In 1931, the publishing of K. Gödel's paper Über formal unentscheidbare Sätze der Principia Mathematica und verwandter Systeme I brought new light on the problem of the acceptability of self-referential sentences in the foundations of Mathematics. His first "incompleteness theorem" states that any effectively generated theory capable of expressing elementary arithmetic cannot be both consistent and complete. The second theorem states that for any formal effectively generated theory $\mathrm{T}$ including basic arithmetical truths and also certain truths about formal provability, $\mathrm{T}$ includes a statement of its own consistency if and only if $\mathrm{T}$ is inconsistent.

After Gödel the reassessment to self-reference is free from the blame of formal contradiction regarding some cases of self-referential sentences. One needs to distinguish between self-reference and idle circularity which leads to the distinction between paradoxes and contradictions. A contradiction entails always a false sentence, but a paradox consists

\footnotetext{
${ }^{26}$ Frank P. Ramsey, "Mathematical Logic" in Frank P. Ramsey and Richard B. Braithwaite, The Foundations of Mathematics and other Logical Essays, London, 2001 (reprint from the 1931 edition), pp. 62-81.

${ }^{27}$ Idem, art. cit in op. cit., p. 67.

${ }^{28}$ Idem, art. cit in op. cit., p. 68.
} 
essentially in the impossibility to decide, in the case of a particular sentence, if it is true or false. Genuine paradoxes reveal the principle of a "third" in addition to true and false $\mathrm{e}^{29}$.

Günther approach to the remarkable productiveness of some self-referential paradoxes led him to the evaluation of the Hegelian critique of some formal logical constraints (identity, contradiction, third excluded and formal negation) and also to the investigation of the ontological depth of the paradoxical situation of the principle of the third excluded.

In the 1972 text "A new approach to the logical theory of living systems" Günther begins with a mental experiment ${ }^{30}$.

Imagine a world where the events are reduced to acoustic qualities (sounds). In such world consciousness means consciousness of sound-events without composition or mixture. Everything that occurs happens as sound-event in complete abstraction of other sense-data. Günther calls such mono-sensorial consciousness and world contexture. Take for example melodic sequences of sounds in musical compositions. These connections are events made by sounds inside a more general contexture of sounds. Günther calls single contexts these types of events consisting in connections of elements of a contexture.

This mental experiment shows that for a given contexture of sounds is the correspondent consciousness of sounds. But, properly speaking, this is neither a world nor a human consciousness. A consciousness completely absorbed by events of a unique contexture is incapable of differentiation, and a consciousness unable to differentiate is not consciousness. Thus, all living conscious organism organize events situated in a variety of contextures, even if we admit the relative autonomy of the elementary contextures. Günther conceives life as a process of linkage between different contextures.

If we envisage the complexity of contextures of the synthetic living organism we are also able to identify different levels of composition and separation of elementary contextures. Discontexturality occurs whenever one traces contextural distinctions between separate contextures and polycontexturality is a description of the world based on discontexturality and on contextural combinations.

Partially, the object of a polycontextural description of the living is the knowledge of the logical rules for the intersection of different contextures. One needs to learn the appropriate use of disjunction, negation and the excluded third for the consideration of the self-closure and emergence of autonomy in elementary contextures but, on the other side, one shall reject the application of the principle of the excluded third for the cases of intersection, combination and couplings between contextures at the polycontextural level.

Additionally, the application of the excluded third to the production of autonomous contextures reinforces the binary organisation of each contexture, as with the comparable distinctions being / non-being; living / non-living; sound / non-sound; etc.

Thus, what justifies the use of binary combinations of values for the description of the living process is the acknowledgment of discontextural situations and the closure of elementary contextures. The excluded third is a reinforcement of bivalence or, even better, a reflexion of bivalence by means of negation or rejection values.

\footnotetext{
${ }^{29}$ See the concept of "true paradoxes" in E. D. Estévez, El Teorema de Gödel, op. cit., pp. 64-68.

${ }^{30}$ G. Günther, “A new Approach to a Logical Theory of Living Systems” (unpublished manuscript in private possession of Dr. Rudolph Kaehr) available at www.vordenker.de.; Idem, "Negation and Contexture” (unpublished manuscript in possession of Staatsbibliotek zu Berlin - Preussischer Kulturbesitz) available at www.vordenker.de
} 
But, if we take this expression of the excluded third it stands for the rejection of an internal known possibility. This internal known possibility appears as the latent third, or an intruder. The reflexive rejection of the ex(in)cluded third reveals the latency of the third in the limits of the contexture. But this one can't recognize itself by reflexion without this internal reference to what is excluded. Precisely, the excluded must be included in the system in a reflexive form. This is a significant cause of logical paradoxes.

Now, one easily understands why the principles of the transclassical logic can and shall be deduced from the distribution of logical places generated by acceptance and rejection positions with the correspondent reflexive status, across different contextures.

This allows the representation of multiple reflexion centres, multiple negations and the description of effective interconnections between contextures.

One can use the principle of the excluded third as a comparison indicator between classical and transclassical models of logic. According to the classical model the excluded third represents only an objective expression of the exclusive validity of the bivalent option, stands for its objective truth. On the other side, for the transclassical model the excluded third is an effect of reflexion on the conditions of closure and self-reproduction of a mono-contextural bivalent structure and on its closure, but can't ever mean that there aren't other contextures.

\section{On Luhmann's constructivist reassessment to the concepts of Umwelt and Welt}

In his historical studies, R. Brague ${ }^{31}$ identified three discourses on the subject of the world: cosmography, cosmogony and cosmology. According to his interpretation only cosmology is able to include a reflexive principle. Cosmography and cosmogony entail narrations without subject, a world without a reflexive centre.

The ordinary use of the concept of world in our language shows that its meaning refers to a human presence. But the content of the concept denotes a "totality of things" and its order. This double aspect in the content, "totality of things" and "order", is noticeable in the Greek words "panta" (Hesiod and Heraclitus) and "cosmos" (since Homer). Heraclitus's idea of "cosmos", according to fragment DK 22B 30, refers to an internal order and measure, and he identifies two possible holders of the order: men and the gods. By Plato (Timaeus) it is possible to outline the identification of "cosmos" with the heavens and a divine order. This translation of the meaning of cosmos from the initial duality earth - heavens to the heavens is also noticeable by Aristotle. In Gorgias, 507 e 6 and 508 a 4 Plato develops the idea of the objectivity of order, regularity and proportion, and some other moral and aesthetic notions regarding the "cosmos" in opposition to what is not the "cosmos". The identification of the right proportion of things with the proportions of the celestial bodies is associated in Greek science and philosophy with the idea of Theoria as the right reflection of a well-organized reality. These aspects will remain the same in the Aristotelian Physics and Cosmology.

In the Stoic tradition, by Pliny the Elder (Historia Naturalis, II, 1-2), one may notice this "harmonism", and the notion of a self-contained realm which embraces all: 1. Mundum

${ }^{31}$ Cf. R. Brague, Aristote et la Question du Monde, Paris, 2001 ; Idem, "L' Homme du Monde" in Peter Kemp (ed.), Philosophical Problems Today: World And Worldhood / Monde et Mondanéité, Springer, 2004, pp. $29-90$. 
et hoc quodcumque nomine alio caelum appellare libuit, cuius circumflexu degunt cuncta, numen esse credi par est, aeternum, inmensum, neque genitum neque interiturum umquam. huius extera indagare nec interest hominum nec capit humanae coniectura mentis. 2. sacer est, aeternus, immensus, totus in toto, immo vero ipse totum, infinitus ac finito similis, omnium rerum certus et similis incerto, extra intra cuncta conplexus in se, idemque rerum naturae opus et rerum ipsa natura.

The text of the Natural History uses "World" (Mundus) with the restricted meaning of Earth but also with the larger meaning of a Universe inhabited by all the things "that are".

From the XVI century to the present a new association was added to the "world" relating it to a method of representation of an entirely outer space or "cartography", for example by A. Ortelius $^{32}$.

But I would like to emphasize how reflexivity is overall important and not only associated with the case of more evident subjective dependent forms of world descriptions. This means that the distinction between degrees of reflexive (subjective) structures in the case of cosmography, cosmogony and cosmology may be only apparent.

In the contemporary sociological literature, by Luhmann, the depiction of the idea of world of the "Semantics of Old Europe" entails the notion of a "universitas rerum" 33 which symbolizes an historical world, which was a closed universe conceived as a replica of a natural realm created on the intelligence and volition of God, an independent order from the finite observers and from finite reflexion. He conceived this natural, "irreflexive", independent order, as identical with the ancient idea of Being and he outlined an explanation of this ontological tradition in a way familiar to Günther's own approach.

The novelty lies on the essay to establish a relation between the tradition of the irreflexive Ontology and the social type of differentiation of the ancient world. Thus, an autological (self-referential) tie links the ancient ontological semantics to the structure of ancient society and its forms of internal reflexion.

Instead of this idea of an independent order he conceived modern society as a form of society characterized by a selbsterzeugter UngewiBheit, or "self-generated uncertainty", a social model at the opposite pole of the old conception of order. Thus, modern society and the concept of an irreflexive order are incompatible ideas.

In the group of papers published by Luhmann in 1972 under the title Soziologische Aufklärung I one finds the title "Reflexive Mechanismen"34. This is a significant textual circumstance that attests the importance of Luhmann's reference to a concept of "social reality" provided with a reflexive structure.

${ }^{32}$ G. Mangani, “Ortelius's Typus Orbis Terrarum (1570)”. Paper presented at the 18th International Conference for the History of Cartography (Athens, 11-16th July 1999), in a "Theory Session" with Lucia Nuti (University of Pisa), Peter van der Krogt (University of Utrecht), Kess Zandvliet (Rijksmuseum, Amsterdam), presided by Dennis Reinhartz (University of Texas at Arlington).

33 The expression "universitas rerum" was usual in Roman Law in order to refer "the totality of things", an "aggregate of individual things" or a "collection of goods" and from Roman Law was received in Canon and Civil Law, was used by Cicero and regain importance in Theology and Cosmology, possibly since J. Scotus Eriugena's Periphyseon. About this last meaning see A. Speer, Die entdeckte Natur. Untersuchungen zu Begründungsversuchen einer "Scientia Naturalis” im 12. Jahrhundert, Leiden, New York, Köln, 1995, pp. 252-264.

${ }^{34}$ See N. Luhmann, "Reflexive Mechanismen” in Idem, Soziologische Aufklärung I, Opladen, 1972, pp. 92-112. 
According to this text the acknowledgment of a reflexive structure of social reality is a relative recent acquisition contrasting with the XIX century factorial theories. The recent interest in complexity problems of modern societies led to an increasing attention to the processes of "reduction of complexity", to mechanisms of simplification and discharge. Even if one didn't yet possess a complete conception of the "reduction of complexity" four main directions point to it: T. Parsons's theory of "generalized media of interchange", A. Gehlen's conception of institution, the "cybernetic theory of machines" (R. Ashby) and the generalized interest for the process of decision in the "social sciences" 35 . In the epoch of the 1970's Luhmann's challenge was to establish a precise formula for the "reduction of complexity" between "action" and "system". This involves consequences for the understanding of the socalled Handlungsrationalität and, historical-theoretically, to the clarification of M. Weber's contribution to the contemporary problems of social complexity. At the end of the paper Luhmann was unambiguous: wir können Handlungsrationalität als reflexiven Mechanismus, nicht aber reflexive Mechanismen als Handlungsrationalität begreifen ${ }^{36}$.

In the absence of a strong semantic permanence of the ancient concept of order and as a consequence of the transformation of the value of the action / system binomium, modern society generated other semantic equivalents in order to autologically reflect its internal structure, form of differentiation and "complexity reduction". The Theory of Systems is engendered as one of these reflexive symptoms.

The phenomenological concept of horizon and Husserl's notion of world ${ }^{37}$ as an ideal limit of acts of reference structured by meaning alongside the differential actuality / potentiality, H. von Foerster's second order cybernetics ${ }^{38}$ and its implications on the idea of an "internal environment" of systems, G. Günther's Morphogrammatic ${ }^{39}$ and Spencer Brown's Logic of Form ${ }^{40}$ can be seen as the four major underpinnings of the use of the concepts of Welt and Umwelt in Luhmann's Theory of Systems.

The frame for Luhmann's Günther reception is given by his theory of social systems, namely the aspects concerning system's internal reflexion, the operative closure of partial autopoiesis and the notion of coupling, or the concept of observation. However, seems clear that regarding the Theory of Systems poly-contextural ontology represents a meta-theoretical level.

I would suggest a formula: the frame for a theory of social systems is self-reflexive and raises meta-theoretical questions. These meta-theoretical questions can't be completely solved by theory itself, even if one conceives theory (sociological theory) as an autological result of modern society $^{41}$.

${ }^{35}$ Idem, ibid., in op. cit, p. 104.

${ }^{36}$ Idem, ibid., in op. cit, p. 108.

${ }^{37}$ Concerning Husserl's concept see Idem, „Soziologie als Theorie sozialer Systeme“ in Idem, Soziologische Aufklärung I, op. cit., „II. Welt als Problem“, pp. 114-116.

${ }^{38}$ H. Von Foerster, Wissen und Gewissen. Versuch einer Brücke, Frankfurt/M., 1993.

${ }^{39}$ See Luhmann's brief account of his interest in Günther in N. Luhmann, Beobachtungen der Moderne, Opladen, 1992, p. 97.

${ }^{40}$ G. Spencer Brown, Laws of Form / Gesetze der Form, Internationale Ausgabe, Lübeck, 1997.

${ }^{41}$ See N. Luhmann, Einführung in die Theorie der Gesellschaft, Heidelberg, 2005, „Selbstbeschreibung“, pp. 286333. Some aspects of this problem were recently scrutinized by G. Kneer, "Reflexive Beobachtung zweiter Ordnung. 
Continuing, I would say that theory raises meta-theoretical problems typical of theory itself.

Additionally, we shall ask: in what sense may we say that the autological line linking semantics to theory also includes meta-theory?

To answer these difficult questions linking theory, meta-theoretical projections of theory and semantics we have to conceive a creative self-referential model for the association between the three aspects. In a straight line, this entails very interesting discussions regarding the relations of Philosophy, Sociological Theory and semantics of modern society.

But one should perhaps go even further.

Luhmann's conception of social systems is intimately connected with his appreciation of modern society's capacity for the generation of partial orders provided with circular autonomy of operative connections between similar elements (partial autopoiesis). This is mainly due to the central evolutionary acquisition regarding the autonomy between communication and consciousness, differentiating social systems and psychic systems.

In modern society, the formation of partial systems is both historically and sociologically confirmed and it is an aspect of the privatisation of world images and world reflexion.

Thus, the Theory of modern Society needs the appropriate concept of reflexion at the meta-theorethical level. The polycontextural theory with its idea of the "rejection values" is a theory of reflexion and negation very useful for the description of the generation of autonomous partial autopoiesis in the System of Society.

Besides, polycontextural logic is the convenient meta-theoretical ground for the integration of the semantic symptoms of modern contextural and discontextural conditions.

I will mention four main directions of the autological tie of the meta-theoretical, polycontextural, explanation and the theoretical level of a Theory of Systems of modern Society.

1. The evolutionary attestation of social differentiation through systemic differentiation was (is) object of sociological and historical enquiry and theoretically demands a concept of internal reflexion or double environment of systems. This is a problem with close relations to Günther's idea of "double reflexion" and von Foerster's "second-order Cybernetics".

2. An operational analysis of the excluded third with regard to the self-closure of social systems is able to show how systems can establish reflexive relations to their environments mobilizing binary classifications of events and meaning without violate the integrity of an alien systemic binary classification and preserve their own identity, by excluding other combinations.

3. Additionally, the richness and complexity of relations is better disclosed if we observe connections between partial systems by means of information processing grounded on selfreferential (partial) binary classifications and transjunctional intersections. One can say that partial systems operate as contextures in front of other contextures in order to process meaning sequences, maintaining or not previous meaning selections. Luhmann's concept of systemic couplings illustrates this aspect combining binary classifications, morphogenesis, evolution and typical transjunctional relations.

Zur Modernisierung gesellschaftlicher Selbstbeschreibung" in H.-J. Giegel und U. Schimank (Hrsg.), Beobachter der Moderne. Beiträge zu Niklas Luhmanns „Die Gesellschaft der Gesellschaft", Frankfurt / M., 2003, pp. 301-332. 
4. Polycontextural ontology continues to be the best meta-theoretical source even in the case of the elaboration of the opposition system / environment through the model of form / medium opposition which inspired Luhmann's late writings in connection with his readings of F. Heider and G. Spencer-Brown. Also in the case of medium / form model we have to envisage acceptance $v$ s. rejection values.

The importance of a meta-theoretical clarification of polycontextural relations also occurs in another aspect I wish to emphasize now, separately.

I'm referring to the problem of the formation of boundaries between system and environment (Umwelt).

One of the controversial points of the Theory of Systems is the thesis of the possibility of observation through communication systems and by communication. According to this idea, observation is not an exclusive predicate of psychic systems, of consciousness and psychic perception, but it is a general evolutionary achievement of all living and meaning systems, a consequence of a more general self-awareness.

The controversy is mainly due to the habit of the association of observation and consciousness.

But, this aspect of the theory that ascribes observation to living and meaning systems generally speaking is easily explainable by its cybernetic underpinnings.

In agreement with the phenomenological style, Luhmann says that the environment is the general horizon for the information processing of the system and its hetero-reference.

But, in Ökologische Kommunikation, continuing his earlier analysis of actuality and potentiality he explicitly wrote the following.

Nur sehr weniges kann jeweils aktuell im Zentrum der Aufmerksamkeit stehen bzw. ein aktuell behandeltes Thema der Kommunikation sein; alles übrige und schlieblich die Welt im ganzen wird durch Verweisungen heranassoziiert und ist dann nur sequentiell und nur selektiv zugänglich(...) In diesem Sinne hat Husserl die Welt als Horizont aktueller Intentionen beschrieben; sie wird nur als Horizon und nich als universitas rerum aktuell ${ }^{42}$.

This was the general view for the discussion of the concept of "Resonanz" and the systemic interpretation of ecological problems of modern society.

With the resonance category Luhmann intended to explain why society is never "in touch" with "reality", "nature", "natural environment" or "world", but communicative systems treat information always by mediation of the previous distinction border of social systems and environment, which entails a complex history of the formation of borders, environments and systemic enclosures.

One shall say, then, that ecological resonance effects in modern society are reverberations of the "natural" environment in "society" throughout selective meaning connections of social systems and not trough a direct "contact".

The theme of resonance is at the crossing point of the observation of social evolution, selfclosure of systemic operations and the drawing of systemic boundaries. Thus, social "resonance" of so called "ecological risks" is a communicative construction, and not a thing in itself.

${ }^{42}$ N. Luhmann, Ökologische Kommunikation, Opladen, $1990^{3}$, p. 43. 
This reveals the importance of a constructivist systemic topology which will enable a suitable model for these three mentioned aspects.

Moreover, in order to become object of observation, whatever the case may be, there must be a distinction line, a border. This border is itself a meaning effect, selection, and not a "fact", or something "take for granted". But, the border generates conditions for the individuation of meaning and it is an individuated form in itself.

A systemic constructivist topology can't be separate from the concretion of systemic borders and this means necessarily individuation.

Through borders and distinctions something can receive the label of "positive fact" and in order to process communication about facts one shall distinguish between categories of facts, or "facts" from other "facts". According to Ökologische Kommunikation it is the communicative treatment of facts that ensures "resonance" and not extra-mental independence. Also, what counts as individual or single event is dependent on a complex arrangement that can't begin with an abstract (isolated) thing in itself. Analyzing systemic boundaries, we notice that the blending of mediation, reflexion and negation through transjunction Günther had in mind, only occurs on the basis of the unit's genesis.

Observation is a case of reflexive recursion of the unit inside itself, being aware of its internal multiplicity in time (self-division) and of the evolution of the dividing border between itself and its environment. The creation of a multiplicity of images of the self is a condition of this virtual internal environment and consequently the distinction line virtual / real.

However, one shall be attentive to the exemplarity of the concept of reflexive, recursive individuation in the gathering together of all these aspects.

In the chapter 2 of Die Kunst der Gesellschaft Luhmann repeats a similar idea concerning the correspondence between observation and the drawing of a distinction: Alles Beobachten ist das Einsetzen einer Unterscheidung in einen unmarkiert bleibenden Raum, aus dem heraus der Beobachter das Unterscheiden vollzieht. Der Beobachter mub also eine Unterscheidung verwenden, um diesen Unterschied zwischen unmarkiertem und markiertem Raum und zwischen sich selbst und dem, was er bezeichnet, zu erzeugen ${ }^{43}$.

The complexity of the communicative channelling of resonance is mainly due to three features of systemic conditionality or the conditionality of the "marked space".

1. The communicative outcomes of the social system and the dividing operative borders between social, psychic and living systems are ensured by partial social systems and are dependent on the respective partial outcomes and partial environment formations;

2. the unity of the social system is only conditionally possible, always through partial systems own complexity and own image of the unity of society;

3. if an operation is always connected to other operations, then some systemic operations are referred to observation of operations and operations of observation can be connected to other operations of observation.

\footnotetext{
${ }^{43}$ Idem, Die Kunst der Gesellschaff, Frankfurt/M., 1995, p. 92
} 
One should say, then, that the reference to an environment is only possible through the system and through the systemic couplings of the reference-system, conditionally. This was precisely the aspect Günther had in mind with his return to the hegelian notion of mediation and the unity of mediation, negation and reflexion.

If certain meaning connections are present and connected in such and such a way, this means that a distinction or a knot of distinctions was engendered, producing a movement or dislodgment in the actuality / potentiality distinction. Günther depicted this dislodgement with his double concept of pleroma-kenoma.

The environment is evolutionary changeable and consequently, as a dependent variable of an indefinite number of other systemic variables, it is unpredictable. It is expandable, because the treatment of the possibilities and the distinction between possibility and actuality is related to systemic achievements, to the closed operative circular movement carried by its operations, and it is not a fixed difference and magnitude.

Luhmann asserts all these views concerning the environment in a condensed formula: without the self-reference of the system there is no environment.

This approach gives enormous emphasis to the duality of "operative closure" and "cognitive openness", developed with particular substantiation in Das Recht der Gesellschaft.

If the environment is always a correlative notion and not a thing or a collection of things, one should presuppose the reference to the world always by the mediation of the reference to the environment and this one is possible only by the circular self-reference of the operations of the system in their self-enchainment. This requires recursion and complex reflexive mechanisms which are not reducible to human consciousness, but rather entails other forms of self-awareness which were included in Günther's expanded model of “analogia entis”.

In modern society this implies self-referential problems in an unusual form. In some cases what an object is depends completely on communicative interpretative rules.

Contemporary art of the functionally differentiated society exemplifies this characteristic of selfreferential systems: what in the environment is object of "art" exhibits a communicative (interpretative) solution for the question concerning the predicate "art".

Thus, we can understand how self-reference enables hetero-reference. Hetero-reference is an evolutionary result of "reflexive mechanisms" at the crossing point of operative closure and cognitive openness in systems.

From the point of view of the epistemological realism this entails a paradoxical situation, but the systemic concept of hetero-reference and the distinction between operative closure and cognitive openness accept the costs of such paradox.

This idea was clearly articulated in the last Luhmann's work, Die Gesellschaft der Gesellschaft when the author wrote that, die Welt nicht mehr als Prinzip, sondern nur noch als paradox behauptet werden kann ${ }^{44}$.

What justifies this positive acknowledgment of paradoxes?

The complete concept of observation entails the operative closure of the meaning systems twice: at a first time as a blind result; at a second time through the formation of a double environment, the so-called „internal“ and „external“ environment, according to H. von Foerster model of the second-order cybernetics.

\footnotetext{
${ }^{44}$ Idem, Die Gesellschaft der Gesellschaft, Frankfurt/M., 1997, 2 vol., vol. 2, p.1144.
} 
The blindness of the distinction between system and world only disappears if the difference itself is further (recursively) appropriated and re-marked in another observation / distinction, thus explaining "second order" observations. This doesn't mean that we now, finally, discovered the world out of the system, but means that the distinction where the world was first referred re-entered and is now indicated.

This implies the internal self-reference of the modal complex displacement along the differences between actuality and potentiality, reality and virtuality, time and simultaneity.

The description of the formation of internal environments shows how the system through its relevancies deals with the blended structure of operative closure and cognitive openness and, consequently, the system itself constantly reconstructs the limit between what qualifies itself and the "world“, by creating an operative internal, recursive, reflexion of the world, structured in such a way that through it the system conceives and manages its own sensitiveness and cognition conditions regarding "what is".

From my theoretical perspective, the double environment concept is useful to explain how one is able to designate individuals "in the world", always on the ground of recursive processes of reflexive centres which are also temporal (or evolutionary) individuation results, in such a way that individuation generates individuation or provisional enclosures.

This is only possible across a re-entry of an initial blind distinction inside of itself, by remarking the modal space where it was initially displayed. This re-marked space has very different significations, depending on the meaning-system used as reference.

It is an important task the discussion of the possibility of language and sign formation on the basis of the logic of distinctions, but it is undeniable that the philosophical discussion about so called modal realism, modal anti-realism, potentiality and actuality, time and simultaneity gains new depth with the poly-contextural, constructivist turn, because from the systemic perspective, described above, one is able to learn a new operative understanding of dynamis as the floor for the permanent transformation of possibilities in actuality and the consequent modal dislocations.

I understand this movement as the general condition for individuation as an infinite process which cannot be without the co-process of knowing and observing and never ends in a state characterized as infima species or in a definitive enclosure of "what is". 